\title{
Minnow Trap Color Effectiveness Test Using Cat Food Bait as Aquatic Sampling Gear on Diurnal Fish in Gajah Mungkur Reservoir, Cental Java, Indonesia
}

\author{
Adityas Arifianto ${ }^{1}$, Elsa Mufti ${ }^{1}$, Agung Pramana Warih Marhendra², Nia Kurniawan ${ }^{2 *}$ \\ ${ }^{1}$ Biology Master Program, Faculty of Mathematics and Natural Sciences, University of Brawijaya, Malang, Indonesia \\ 2Department of Biology, Faculty of Mathematics and Natural Sciences, University of Brawijaya, Malang, Indonesia
}

\begin{abstract}
The Minnow Trap is a simple sampling gear, efficient, easy to operate, affordable, easy to make, and has been used in research in the fisheries and aquatic ecology for more than 90 years. The brightness, color, and visual obstruction of fishing gear or fish traps affect the behavioral response of target fish, considering that each fish has a specific level of color sensitivity. The color effectiveness test of fishing gear is an important prerequisite for the use of sampling tools, and it needs to be evaluated to understand the gear performance and avoid potential sampling bias. The purpose of this study was to test the color effect of the minnow trap on diurnal fish in the Gajah Mungkur Reservoir waters. The research was carried out in Gajah Mungkur Reservoir, Wonogiri Regency, at two stations. The sampling conducted at $09.00-11.00$ and $13.00-15.00$ Indonesian West Time, where the initial survey is estimated to be the highest time for diurnal fish activity. The minnow trap used in this study is four colors vinyl-painted double funnel cylindrical minnow trap with a $5 \times 5$ millimeter mesh size and a conventional umbrella minnow trap used as control. The sampling results are then recorded on the datasheet and analyzed using Microsoft Excel. CPUE (Catch Per Effort Unit) of each unit is then calculated and statistically analyzed by Kruskal-Wallis test and Kolmogorov-Smirnov normality test through SPSS 25.0 software. The test result of five unit minnow traps from 40 installations and two hours of deployment time, 80 individuals were captured, consisted of seven species of freshwater fish. CPUE values ranking consecutively from the highest from silver units (1.375), black (1.25), green (1.125), red (0.9375), and control (0.3125). The Kruskal-Wallis analysis showed that all tested units do not have a significant difference.
\end{abstract}

Keywords: Color, catch per unit effort, fish, minnow trap.

\section{INTRODUCTION}

A minnow trap is a small fish trap with a funnel-shaped entrance on the side of a box or a cylinder-shaped net. The standard minnow trap design is often used for fish or crustacean sampling to collect aquatic ecological data. Minnow traps are classified as passive sampling devices because it rellies on fish to actively find and are interested in entering the trap [1]. The efficiency and selectivity of small fish traps are influenced by the probability that fish will meet, enter, and hold in the trap until they are taken [2]. The term minnow is used as a general term referring to small fish used as fishing bait. However, the true minnow taxonomically is given to freshwater fish that belong to the Cyprinidae family, which includes small species and juvenile schooling. The term minnow also applies to fish from the Poeciliidae family, such as Guppy, Molly, Platy, and Swordtail [3]. The size of fish caught in a minnow trap is limited by the size of the entrance, which is usually relatively small (20$30 \mathrm{~mm}$ ). The Minnow traps can be effectively

\footnotetext{
* Correspondence address:

Nia Kurniawan

Email : wawanunibraw@gmail.com

Address : Biology Master Program, University of Brawijaya, MT. Haryono 169, Malang 65145
}

used to catch small freshwater fish samples in various wetland environments, including lakes, swamps, rivers, and ponds. The trapped fish samples are not damaged and can be released alive after being caught. Gill nets or angling methods usually cause mortality on fish, and predation also occurred in large-scale passive gear traps such as Fyke Net. Because of their small size, minnow traps can also be installed between complex habitats and small water pools or narrow waterways [4].

Minnow trap has been used as sampling gear in ichthyology and freshwater ecology studies for more than 90 years [5]. The design of the minnow trap is relatively simple, efficient, easy to operate, less expensive, and has been widely used for freshwater organisms sampling. Research and literature on the effectiveness of trap minnow traps have been studied in previous research regarding color effectiveness $[6,7]$. But there has never been researched on the use of minnow traps in tropical freshwater in Indonesia. Statistical test on the effectiveness and selectivity of fishing gear is essential to be measured for the use of a sampling tool when the data are intended for quantitative comparison [8]. Catch efficiency of various colors of fish traps needs to be evaluated to avoid potential sampling bias because the brightness 
and visual obstruction of the fishing gear affect the response behavior of the target fish [9].

Fishing gear visibility underwater depends on water turbidity and contrasts with the background of the habitat, which can be affected by seasonal changes in water turbidity color due to dissolved sediment or eutrophication. Andreev [10] recommends using darker nets or traps in clear water but using brighter colors in turbid water. Fish can distinguish colors, and different colors of fishing gear can determine the target. Fish retina generally has rod and cone cells. Fish vision is mediated by four visual pigments that absorb various wavelengths of light. Each pigment is constructed from chromophore and transmembrane proteins, known as opsins. Mutations in opsin have allowed for a wide range of variations in the absorption of wavelengths [11].

Some types of fish can see ultraviolet, and others are sensitive to polarized light. For example, Neumeyer [12] showed that minnows (Phoxinus laevis) were able to distinguish red, yellow, green, and blue colors from their irradiation levels. It shows that the minnows of the family Cyprinidae have excellent color vision on a par with mammals. Another study in 2017 also found the ability to see an even wider range of colors in the cichlid family [13]. These specifications lead to the idea that further research is necessary to determine the pattern of target sensitivity on trap color. This study is expected to be a reference in the standardization of fish sampling methods using minnow traps, especially in freshwater aquatic habitats in Indonesia.

\section{MATERIALS AND METHODS}

This study was conducted by experimenting with a sampling method using minnow traps by coloring treatment as an independent variable. The minnow trap that used in this study is a double funnel cylindrical minnow trap with $40 \mathrm{~cm}$ length, $30 \mathrm{~cm}$ funnel diameter, and $7 \mathrm{~cm}$ funnel entrance. The material of the trap is mesh wire coated with vinyl paint (red, silver, black and green) with a mesh size of $5 \times 5 \mathrm{~mm}$ (Fig.1). The control of this experiment is foldable six funnels Umbrella Minnow Fish Trap with $100 \times 100 \times 40 \mathrm{~cm}$ and $2 \times 2 \mathrm{~mm}$ mesh size. The purpose of using different shapes of minnow trap as control is to compare double funnel minnow trap with foldable umbrella minnow trap conventional sampling gear.

The research was conducted at Gajah Mungkur reservoir, Wonogiri district. The sampling process is conducted at two predetermined sampling stations:

- Sendang (-7.845784, 110.920640)

- Gumiwanglor (-7.876840, 110.894266)

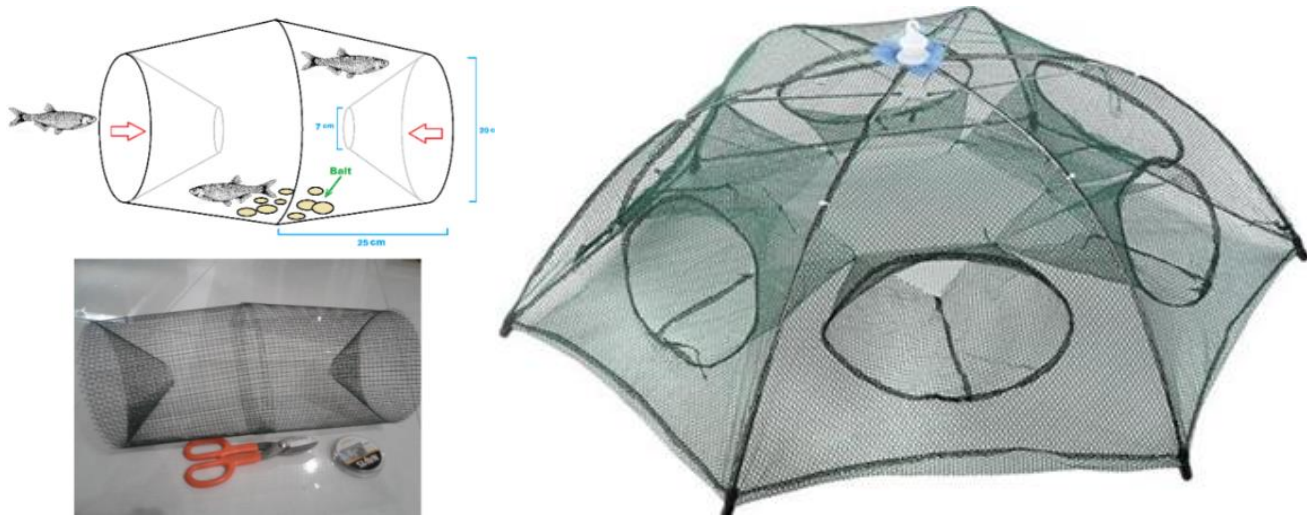

Figure 1. Double funnel cylindrical minnow trap and portable umbrella minnow trap

\section{Site Description}

This research was conducted in Gajah Mungkur Reservoir to test the effectiveness and selectivity of minnow traps. Gajah Mungkur Reservoir is an artificial lake or dam located at an altitude of 190 above sea level, an area of 8,800 ha (almost $90 \mathrm{~km}^{2}$ ) with a maximum depth of 136 meters, which is located $7 \mathrm{~km}$ south of Wonogiri City just downstream of the Keduang River, Wonogiri Regency, Province Central Java. Gajah
Mungkur is a multipurpose reservoir with the main function of irrigation, hydroelectric power, drinking water sources, tourism, fishing spot, and aquaculture. Gajah Mungkur Reservoir was built by damming the longest river in Java, the Bengawan Solo River. Gajah Mungkur Reservoir has six inlets (Keduang stream, Wiroko stream, Wuryantoro stream, Temon stream, Alang - Solo Hulu stream, and Uplahan stream) and one outlet (Fig. 2). 


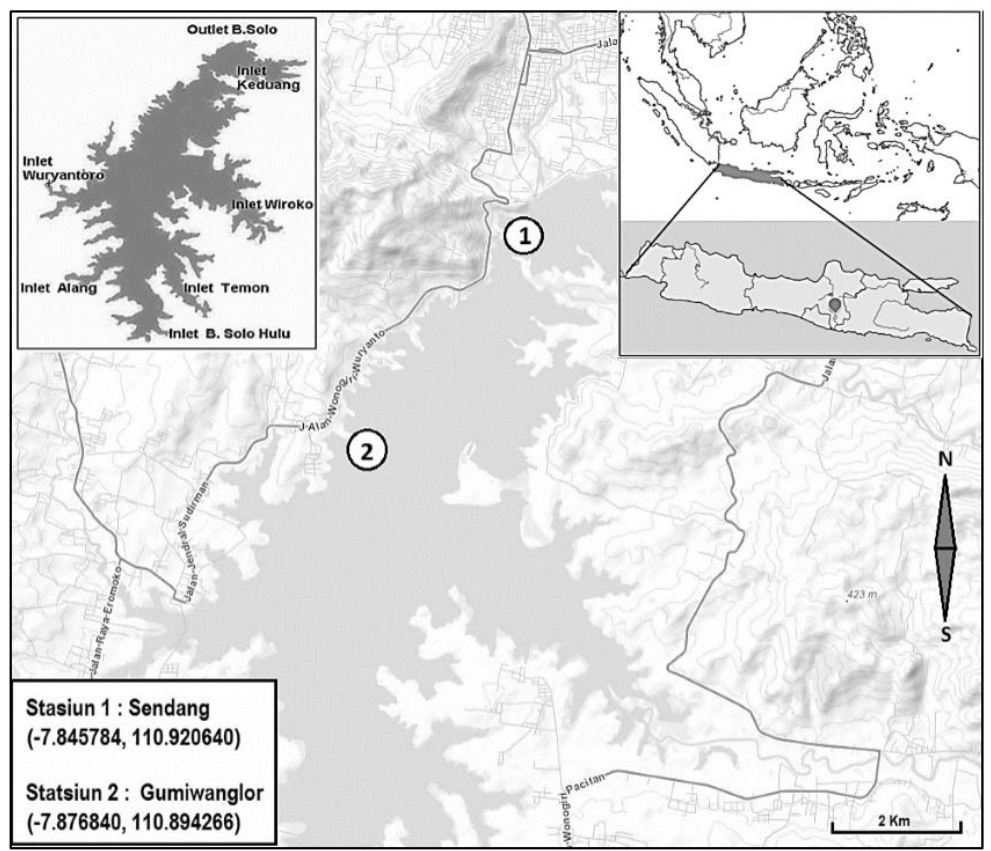

Figure 2. Study site in Gajah Mungkur Reservoir, Central Java

\section{Data Collection}

Survey and pre-sampling are necessary to decide the sampling station and estimate effective trap placement duration and escaping rate. Pre-sampling conducted by trapping at several durations ( 2 hours, 4 hours, and 6 hours) using the same unit. Habitat characteristics observation is carried out as consideration for selecting stations, including slope level, the dominant substrate (boulder, cobble, gravel, sand, clay, or mud), waters color (clear, cloudy, eutrophic), and aquatic vegetation presence.

Table 1. The composition and nutritional value of the used bait.

\begin{tabular}{ll}
\hline \multicolumn{1}{c}{ Composition } & Nutrition Information \\
\hline Tuna extract & Protein (min) $=28 \%$ \\
Fish meat & Fat (min) $=8 \%$ \\
Chicken meat & Rough fiber (max) $=3 \%$ \\
Wheat & $\begin{array}{l}\text { Water concentration } \\
\text { (max) }=10 \%\end{array}$ \\
Corn & \\
Flour & \\
Whole soybean & \\
Taurine & \\
Omega oil & \\
Choline chloride & \\
Niacin & \\
Inositol & \\
Multivitamin ( AD3, E, C, & \\
B1, B2, B6, B12, K3) & \\
Biotin & \\
Folic acid & \\
Dissolved minerals & \\
Yucca schidegra extract & \\
Source: PT. Matahari Sakti &
\end{tabular}

Sampling was conducted by placing all trap units by four repetitions in each station. The traps were placed in the photic zone, approximately $0.5-1$ meter (according to the bank slope level). The trapping duration of each placement is two hours at $09.00-11.00$ and 13.00 - 15.00 West Indonesian Time. The bait that used in this study is dry cat food with the consideration that it contains the main nutrients (protein, fat, and carbohydrates) as well as vitamins and minerals (Table 1 ). Relatively larger granules also make dry cat food easier to apply to the size of the Minnow Trap mesh size. The captured specimens were then contained in the icebox and identified in the laboratory.

\section{Data Analysis}

Analysis using Catch per Unit Effort (CPUE) in this study is used to measure the effectiveness of each minnow trap color (silver, green, black, and red). The efficiency of the fishing gear for the sampling method in the study of water science and ecology can be represented by the ability of the sampling gear to catch fish and other aquatic biotas in a unit of time and repetition called CPUE. The total catch of each fishing gear unit that is tested will be divided by the number of repetitions and time of placement. Furthermore, for being able to measure the efficiency of the sampling method, the CPUE measurement of fishing gear can also be carried out to monitor and estimate the population of an aquatic species when combined with the recapture 
method [14]. The CPUE scale that is used in this study is individuals/units/hour.

$$
\text { CPUE } \boldsymbol{i}=\frac{\text { Total Catch }}{\text { Effort }}
$$

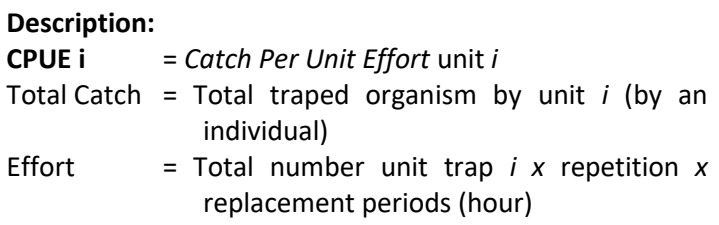

The Kruskal-Wallis statistical tests and Kolmogorov-Smirnov normality tests used in this study followed with Mann-Whitney post hoc test with hypotheses:

- $\mathbf{H}_{0}$ : There is no significant difference between the average catch of minnow trap red, silver, blue, and green minnow traps

- $\mathbf{H}_{1}$ : There is a significant difference between the average catch of the red, silver, blue, and green minnow traps

\section{RESULT AND DISCUSSION}

\section{Catch Per Unit Effort (CPUE)}

The total catch was from 40 sampling processes of 5 unit minnow traps from 40 installations and two hours of deployment time of four colors cylindrical minnow trap units and one portable umbrella minnow trap as controls. We obtained 80 specimens from four families that included six fish species and one freshwater shrimp species. The results of research sampling show that the highest CPUE was possessed silver units (1.37 individuals/hour), followed by black units (1.25 individuals/hour), green (1.12 individuals/hour), and red (0.93 individual/hour). The smallest CPUE is possessed by an umbrella trap as control ( 0.31 individual/hour). The umbrella minnow trap as a control unit has the

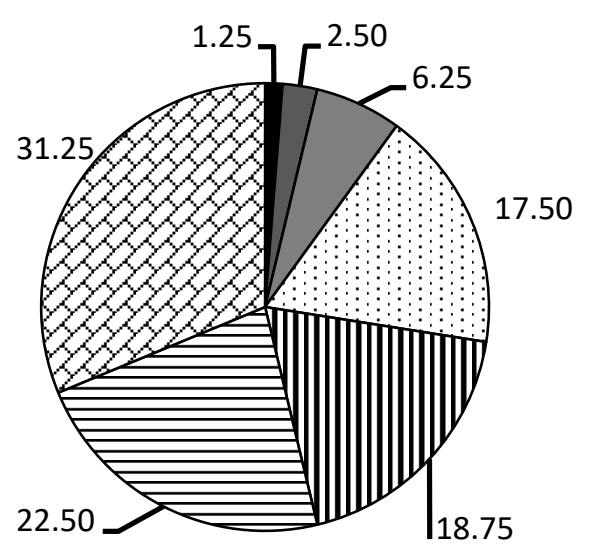

lowest CPUE. It was estimated because of a larger funnel hole that increases the escaping rate of the captured specimen. Umbrella minnow trap also more effective with longer placement duration according to the previous study with 4-6 hours duration [15], compared with this study which only 2 hours duration for each placement.

Invasive Nile Tilapia ( $O$. niloticus) is the highest captured species by minnow traps Total catch was dominated by Cyprinid fish but also consisted of freshwater shrimp and one Goby species. The minnow traps are very effective in habitats that dominated by small Cyprinidae families. An experimental study conducted by Paradis and Dupuch [6] recommended using silver minnow traps because they show high capture ability due to the effects of transparency, and fish tend to enter black-colored minnow traps as a shelter in response to avoid predators. The maximum catch record is possessed by the red unit ( 8 individuals) followed by green ( 7 individuals), silver (6 individuals), black (5 individuals), and the smallest by umbrella minnow trap (4 individuals). The red unit in this study has the highest total catch. It assumes that fish tend to be less sensitive with longwavelength light colors and less aware of trap visibility underwater [13]. The green unit has the second-highest total catch. It assumed that green color would give the trap camouflage on watercolor due to algal eutrophication or mimicking vegetation structure. Relatively lower CPUE of the red and green unit, even with the highest maximum trap, shows that fish tend to easier to enter the red and green trap and also easier to escape and caused unstable catch frequency.

$$
\begin{aligned}
& \text { Species percentage (\%) } \\
& (n=80)
\end{aligned}
$$

\section{Oxyeleotris marmorata}

\section{$\square$ Labiobarbus leptocheilus}

\section{$\square$ Mystacoleucus marginatus}

\section{$\square$ Macrobrachium lanchesteri}

\section{Rasbora argyrotaenia}

\section{$\boxminus$ Barbonymus balleroides}

\section{QOreochromis niloticus}

Figure 3. Total catch composition of all minnow traps. 

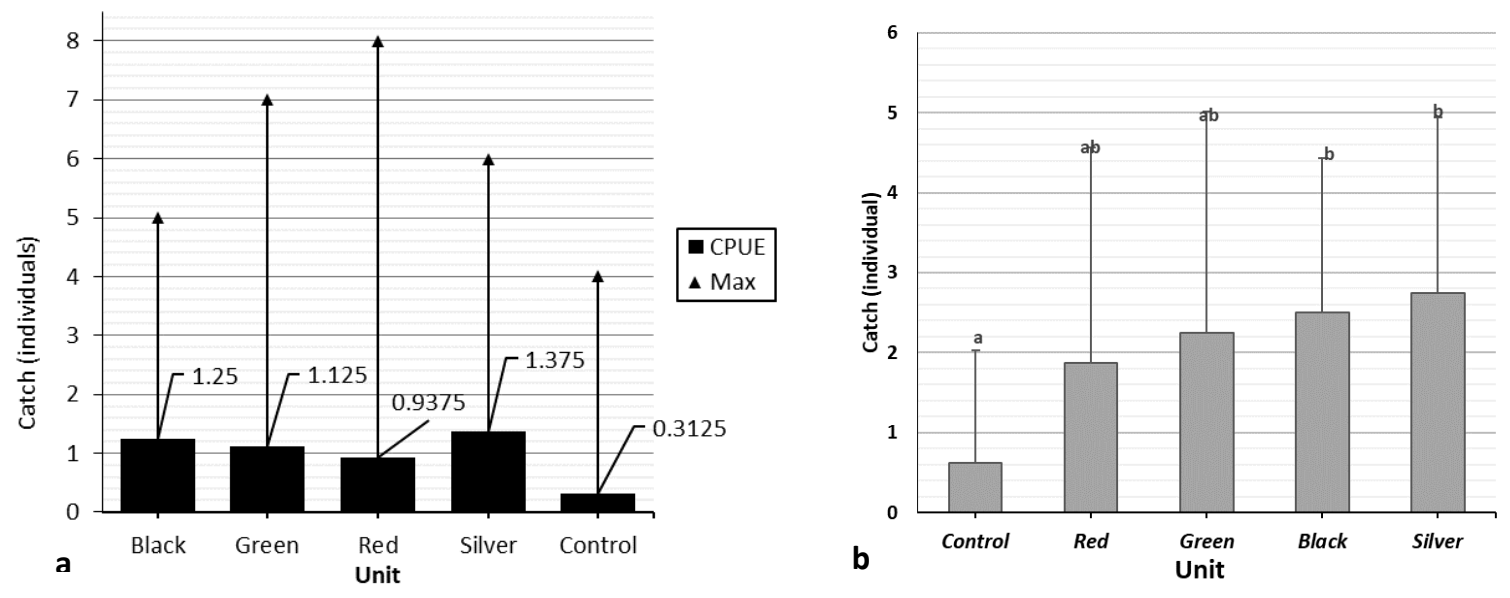

Figure 4. Comparison of a) CPUE value and maximum catch ( 2 hours placement) for each minnow trap unit b)The results of the post-hoc Mann-Whitney analysis of the minnow traps catch

The highest CPUE value in this study was relatively lower compared to the similar experiment by MacRae and Jackson [5] using the silver-colored minnow trap in a community of fish with moderate temperate lakes in the northern hemisphere (mean CPUE $=1.61$ ). The effectiveness of the minnow trap conducted in the brackish waters of the Baltic Sea shows that the silver-colored minnow trap also has the highest CPUE value (2.8 individuals/unit/hour) compared to black and red [7]. Merilä [16] used minnow traps in Rytilampi lake Finland with the result of 1.31 individuals/units/hour for silver minnow traps and 0.20 individual/units/hour for black minnow traps. The CPUE values in this study have a wide range compared to the highest capture value (maximum capture) of each unit (Fig. 4a). The data shows the instability of the catch frequency at each placement.

\section{Statistical Analysis}

Statistical analysis on total catch shows that the data are not homogenous and don't have a normal distribution. Kruskal-Wallis analysis shows the insignificant difference $(\mathrm{df}=4, \mathrm{P}>0.05)$ from 8 replications of 5 tested units unit minnow traps. Mann-Whitney Post Hoc test only shows the difference between unit control with black and silver rather than red and green units (Fig. $4 b)$. The post Hoc test also shows that four units excluded from control don't have a significant difference since the umbrella minnow trap has the largest gap of total catch number with four double funnel minnow trap units. It gives double funnel minnow trap advantages that superior at shorter placement duration [7]. The performance of using minnow traps is not only influenced by the ability of fishing gear to attract fish to enter but also the ability to prevent fish from escaping the fishing gear. It is explained by a larger unit silver CPUE than the darker colored units, which have a bigger escaping rate via funnel holes visibility. The factors of the presence and density of fish communities also have a big influence on the effectiveness of fishing gear. An experiment conducted by Layman and Smith [4] showed that the size of freshwater habitats or water bodies directly increases the bias of the sampling method. Captured number fluctuation is also affected by target movement in large habitat and gives a disadvantage to minnow trap as passive sampling gear.

\section{CONCLUSION}

Five units of tested minnow trap in Gajah Mungkur Reservoir showed that the silvercolored minnow trap unit has the highest CPUE (1.375), followed consecutively by unit black (1.25), green (1.125), red (0.9375), and umbrella minnow trap as control (0.3125). The KruskalWallis analysis showed that all tested units do not have a significant difference. The large margin of data deviations indicates a lack of sampling repetition, data fluctuation is also affected by habitat size. Future research using minnow trap recommended better using a larger number of trap units and avoiding the application of minnow trap on large water bodies habitats.

\section{ACKNOWLEDGEMENT}

My most sincere thanks to all who helped me in the research and writing process of this paper. Especially, my parents who have provided financial support to complete my studies and research. Kartika Prabasari, assisted in providing 
suggestions and solutions in the statistical analysis process. Also to Afina Aninnas and Rahmat Grahadi as laboratory colleagues who helping me in PC accommodation and technical problem assistance.

\section{REFERENCES}

[1] Hubert, W.A., K.L. Pope, J.M. Dettmers. 2012. Passive capture techniques. In: Zale, A.V., D.L. Parrish, T.M. Sutton. Fisheries Techniques, $3^{\text {rd }}$ Ed. American Fisheries Society. Bethesda.

[2] Portt, C.B., G.A. Coker, D.L. Ming, R.G. Randall. 2006. A review of fish sampling methods commonly used in Canadian freshwater habitats. Can. Tech. Rep. Fish. Aquat. Sci. 2604

[3] Hernandez, L.P., A.C. Gibb, L.A. Ferry. 2009. Trophic apparatus in Cyprinodontiform fishes: functional specializations for picking and scraping behaviors. J. Morphol. 270(6). 645-61.

[4] Layman, C., D. Smith. 2001. Sampling bias of minnow traps in shallow aquatic habitats on The Eastern Shore of Virginia. Wetlands. 21. 145-154.

[5] MacRae, P.S., D.A. Jackson. 2006. Characterizing north temperate lake littoral fish assemblages: a comparison between distance sampling and minnow traps. Can. J. Fish. Aquat. Sci. 63(3). 558-568.

[6] Paradis, Y., A. Dupuch, P. Magnan. 2012. comparison of catch efficiencies between black and galvanized minnow traps. N. Am. J. Fish. Manag. 32(3). 539-543.

[7] Budria, A., J. Defaveri, J. Merilä. 2015. Comparison of catch per unit effort among four minnow trap models in the threespined stickleback (Gasterosteus aculeatus) fishery. Sci. Rep. 5(1). 18548.

[8] Kneib, R.T., A.H. Craig. 2001. Efficacy of minnow traps for sampling mummichogs in tidal marshes. Estuaries. 24(6): 884.

[9] Rowland, W.J. 1999. Studying visual cues in fish behavior: a review of ethological techniques. Environment. Biol. Fishes. 56. 285-305.

[10] Andreev, N.H. 1955. Some problems in the theory of the capture of fish by gillnets. 30 . 109-127. Transl. from Russian by Fisheries Laboratory. Lowestoft, England.

[11] Yokoyama, S., R. Yokoyama. 1996. Adaptive evolution of photoreceptors and visual pigments in vertebrates. Annu. Rev. Ecol. Systemat. 27. 543-567.
[12] Neumeyer, C. 2003. Color vision in fishes and its neural basis. In: Collin, S.P., N.J. Marshall (Eds). Sensory Processing In Aquatic Environments. Springer. New York.

[13] Escobar-Camacho, D., J. Marshall, K.L. Carleton. 2017. Behavioral color vision in a cichlid fish: Metriaclima Benetos. J. Exp. Biol. 220(16). 2887-2899.

[14] Guzzo, M.M., M.D. Rennie, P.J. Blanchfield. 2014. Evaluating the relationship between mean catch per unit effort and abundance for littoral Cyprinids in small boreal shield lakes. Fish. Res. 150. 100-108.

[15] Diana, C.M., J. Jonas, R.M. Claramunt, J.D. Fitzsimons, J.E. Marsden. 2006. A comparison of methods for sampling round goby in rocky littoral areas. N. Am. J. Fish. Manag. 26. 514-522.

[16] Merilä, J. 2015. Baiting improves CPUE in nine-spined stickleback (Pungitius pungitius) minnow trap fishery. Ecol. Evol. 5(17). 3737-3742. 